\title{
IN PURSUIT OF AN ÆSIRIST IDEOLOGY
}

\author{
Richard Cole
}

The most elementary definition of ideology is probably the well-known phrase from Marx's Capital: 'Sie wissen das nicht, aber sie tun es' - 'they do not know it, but they are doing it. The very concept of ideology implies a kind of basic naiveté: the misrecognition of its own presuppositions.

Slavoj Žižek, The Sublime Object of Ideology $(2008,24)$

\section{A Definition of Ideology}

Ideology has been a recurrent topic in Old Norse studies. Some researchers discuss ideology as an applied phenomenon, i.e. as an assemblage of ideas concerning who should occupy particular positions of authority in society and by which titles they ought to do so. This is particularly true in the case of research focusing on 'royal ideology' (e.g. Clunies Ross 2014; Ármann Jakobsson 1999 and 2015; Bagge 1993, 1991a, 1991b). One might also speak of an ideology less directly pertinent to constitutional matters though still concerned with power and ethics, e.g. Carl Phelpstead's exploration of 'sexual ideology' in Hrólfs saga kraka (2003). Ideology is a malleable concept, which will make sense in most contexts whether one uses the sophisticated definition of a philosopher or the layman's understanding of the word, as per the Oxford English Dictionary: '[Ideology is a] systematic scheme of ideas, usually relating to politics, economics, or society and forming the basis of action or policy; a set of beliefs governing conduct' (OED 2010, s.v. 'ideology').

\section{Richard Cole is an Assistant Professor of Medieval History at Aarhus University.}

Abstract: Is it possible for characters in fiction to be motivated by unique ideologies in the way that political movements are in real life? This essay considers the example of the Æsir (the dominant tribe of gods) in Snorri Sturluson's Prose Edda. Analogies with later ideologies are offered as a way to highlight the idiosyncratic ideological brew which seems to govern the Æsir's actions. The Æsir have the acquisitiveness, violence, and sexual neurosis of a colonial regime. They have the reactionary's aptitude for cynical manipulation of history. They have the frailties of the modern capitalist. These comparisons are used to sketch out an ideology which is more than the sum of its comparanda: Æsirism.

Keywords: colonialism, giants, ideology, mythology, Old Norse, Prose Edda, racial fetishism, Ragnarǫk, Sámis, Æsir

Viking and Medieval Scandinavia 15 (2019), 65-101 BREPOLS PUBLISHERS DOI 10.1484/J.VMS.5.118631 
Gro Steinsland, in the introduction to an edited collection which attempted to draw researchers' interest in Old Norse topics to questions of ideology, recommended the advantages to letting the term go without a strict definition:

There are many discussions of the term ideology, and it is not our intent to provide yet another complicated definition. Suffice to say that ideology differs from mentality in that the latter refers to a more subconscious, vague, and possibly quotidian understanding of life and the world, while the former concerns systems of thought formulated with a greater degree of intention. These thought-complexes are relatively systematised, yet not necessarily analytical. (2011a, 4)

Conveniently, this 'definition by non-definition' resonates with the understanding of ideology provided by Slavoj Žižek in The Sublime Object of Ideology. As per the epigraph to this study, Żižek highlights the potential unconsciousness, unreflectedness, and sometimes disingenuity of ideological positions (2008, 15-16, 23-30). Put shortly, Žižek stresses that ideology does not need to be communicated in lucid manifestos. Ideologies which are particularly detailed and complex might be preserved in weighty, self-consciously political tomes, but like Terry Pratchett's 'small gods', there are in fact lesser, half-formed ideologies swirling in every banal object and social transaction: Kinder Surprise chocolate eggs communicate the capitalist dream of surplus value (Žižek 2003, 145-49: somehow a Kinder Egg is more desirable than the sum of its constituent parts, chocolate and toy, just as a commodity is valued more than the sum of labour and raw materials). ${ }^{1} \mathrm{~A}$ face idly doodled on a serviette in a Chinese takeaway can be read as a symptom of anthropocentrism: the blinkered view of ecology which has precipitated environmental crisis (Deleuze and Guattari 2011, 128-30, 202-04). The glossy magazine Elle can be read not as a fluffy distraction, but as 'say [ing] to women: you are worth just as much as men; and to men: your women will never be anything but women' (Barthes 1972, 151). The omnipresence of ideology suggests the possibility of finding ideology even in fictional worlds such as Snorri's Edda, and thus prompts the present study. In what follows, I identify to what extent the Æsir in Snorri's account are driven by a coherent ideology. Put another way: what is Æsirism? And what does it believe about the world?

\section{Esirism as Opposed to Authentic Beliefs}

This essay accepts that Snorri Sturluson composed his Prose Edda in Iceland in the 1220s, although we cannot know that he did not compose portions of

${ }^{1}$ To a great extent, Žižek is pre-empted by Roland Barthes, although Barthes is of a more semiotic bent (1972, esp. 109-59). 
the work during one of his sojourns in Norway. Whether Snorri composed the $E d d a$, whether he compiled it, or how much of the work ought to be attributed to him, are not completely resolved matters (Clunies Ross 2005, 161-63; cf. von See 2001, 367-93). For present purposes all that needs to be said on these questions is to admit that I adopt the attitude of Kevin Wanner: 'my entire project is a contribution to the case for Snorri's more-or-less direct authorship' $(2008,26-28) .^{2}$ Even though it is not the impetus of this piece to fortify the case that Snorri was the author, my arguments will tangentially show that the ideological concerns of the $E d d a$ are consonant with what we otherwise know of the political concerns of Snorri's life and times.

The Edda tells the story of how the race of gods, the Æsir, created the world, undertook various escapades where they triumphed against the hostile race of giants, convinced human beings to worship them, and how they will finally be undone at the end of the world, which Snorri called Ragnarøkr (the twilight of the gods). To tell this web of stories Snorri introduces a narrative frame. It is explained that there was a human king named Gylfi who ruled over Sweden. The Æsir arrived to settle in Scandinavia, and they invited Gylfi to their hall, Ásgarðr, where Óđinn disguises himself as three beings, Hár (High), Jafnhár (Just-asHigh), and Driði (the Third One), and attempts to persuade Gylfi that he and the other Æsir are gods.

Gylfi needs to be convinced of this, and he interrogates the three guises of Óðinn with questions about the origin of the world and the deeds of Æsir. In the frame-narrative, Snorri provides a euhemerist explanation of Scandinavian paganism, i.e. that the Æsir were actually not divine. They were instead very good magicians who wished to trick Gylfi. In the answers which the incognito Oðinn provides to Gylfi, it is then taken for granted that the Æsir really are gods. The frame and the core narrative function as an internally consistent text so long as one accepts that Óðinn/Hár/Jafnhár/Priði is being somewhat disingenuous in some of the versions of the myths which he tells to Gylfi. Indeed, Snorri himself strongly suggests to his audience that Óðinn's words are never quite to be trusted. The Æsir set up sjónhverfingar (optical illusions) to trick Gylfi into worshipping

${ }^{2}$ For my own part, I incline towards a variant on Jean-Paul Sartre's famous aphorism on antiSemitism: 'if Snorri did not exist, the philologist would invent him'. That is to say, even without Snorri's name on DG 11 4to, and the attribution in the sixteenth-century Oddaverjaannáll, we would suspect that the author of the Edda was an Icelander (because of the skaldic verse in the $E d d a$ ), active in Norway (because of the repeated mentions of the Norwegian royal line), not a cleric (because of the lack of Latin quotations), and with an interest in mythology (as shall be discussed later, Snorri supposedly named his tent at Pingvellir Valholl, and was quizzed on mythological matters by Duke Skúli). 
them. In another work by Snorri, Ynglinga saga, it is hinted that Óðinn was more convincing than he was candid: 'hann talaði svá snjallt ok slétt, at ollum, er á heyrðu, pótti pat eina satt' (Snorri Sturluson in Bjarni Aðalbjarnarson 1941, 17) (he spoke so eloquently and smoothly that everybody who listened to him thought it to be entirely true). ${ }^{3}$

It must be underlined that the aim of this study is to present the ideology of the Æsir as presented in Snorra Edda. It entails literary criticism, focused on one work, rather than mythic criticism, which might offer a totalizing view of Old Norse mythology across multiple sources. This is a distinct enterprise from presenting the ideological commitments of actual pre-Christian Scandinavians. A Norwegian Viking in the year 800 would have inhabited a very different world, both mentally and politically, from our Icelandic author in the 1220s. Snorri was obviously a Christian, whilst many Vikings would have been pagan. Snorri probably had some sort of identity as an Icelander as well as a Norwegian, while Iceland had not yet been settled during the first decades of the Viking Age. During Snorri's lifetime, there was an increasing likelihood that Iceland would become subject to the Norwegian Crown. He would eventually be assassinated on the orders of his former son-in-law, Gizurr Porvaldsson (d. 1268) because he had backed the wrong side in the Norwegian civil war of 1239-40. For much of the pagan period, however, Norway did not even exist as a unified state. If the idea of 'Norway' existed in people's imaginations, what existed in reality was a patchwork of petty states and local assemblies. Snorri's age was the time of the University of Paris, of the Fifth Crusade, of the first Dominicans. The Viking Age was the time of Charlemagne, the House of Wessex, and the Khazars.

This is not to say that the ideology exhibited by the Æsir in Snorri's selfconsciously fictional, thirteenth-century account is entirely divorced from the ideology that governed people who authentically believed in the existence of the Æsir during the Viking Age. A principal source used by Snorri were the poems now found in the Poetic Edda (also known as Semundar Edda or the Elder $E d d a)$. This body of poetry is now known from a manuscript from the year 1270 , but much of it is undoubtedly a great deal older, quite possibly as old as the Viking Age in many cases. Most likely, the ideology that Snorri bestowed on the Æsir in his literary act of subcreation is therefore a mosaic of contemporary political thought from the thirteenth century, interspersed with occasional atavistic fragments that would have been recognizable to an archetypal Viking. ${ }^{4}$ Picking apart the thirteenth century from the ninth century will not be our

\footnotetext{
${ }^{3}$ All translations are my own.

${ }^{4}$ On subcreation and the construction of mythological worlds, see Phelpstead 2014.
} 
chief business here, however. Rather, we will focus on the ideology that the Æsir appear to exhibit judging by the words and deeds that Snorri attributes to them in his Edda. As Margaret Clunies Ross says of the business of tracing the mental framework of characters in Old Norse literature more generally: 'For the most part characters are seen in action and their nature and motives may be deduced from what they do, what others, including the narrator's voice, say about them and, sometimes, what they reveal in their own words' $(1994,43)$. As my interest is in Snorri's Edda as an independent work, I will therefore generally not take into account material from the Poetic Edda or other sources outside of Snorri's opus, unless the version presented by Snorri is sufficiently divergent that his own additions are worth commenting upon.

\section{Colonial Considerations: Sex, Race, Labour}

Elsewhere, I have treated the problem of political organization in Æsirism (Cole forthcoming). I suggest that the Æsir, as imagined by Snorri, are committed to a kingless state, which gives at least a pretence of self-determination to the 'in-group', i.e. the gods themselves. In the same study, I explored the extent to which the relationship between the Æsir and the 'out-group', i.e. the giants, can be understood in colonial terms. One way to read Snorra Edda is that the Æsir have built their world using violence against the giants, and finally relegated them to the least desirable fringes of the universe. Although the Æsir have marginalized the giants, they apparently make no effort to destroy them completely. The gods enjoy technological superiority over the giants, thanks to Pórr and his mighty hammer, Mjǫllnir 'er hrímpursar ok bergrisar kenna pá er hann kemr á lopt, ok er pat eigi undarligt: hann hefir lamit margan haus á feðrum eða frændum peira' (Snorri Sturluson in Faulkes 1988, 23) (which the Ice-Giants and Mountain-Giants recognize when he holds it aloft, and that's no strange thing: it has crushed the skulls of many of their fathers or their kinsmen). ${ }^{5}$ Presumably a giant genocide would not be an impossible undertaking for the gods, and it would forestall Ragnarøkr, preventing the giants from joining the

${ }^{5}$ Codex Regius, fol. 6r; Codex Trajectinus, fol. 6v. An anonymous reviewer expressed concern that Faulkes's edition is too synthetic to represent an authentic medieval tradition. In response, I have checked each quote against the Codex Regius (GKS 2367 4to, c. 1300-50) and Codex Trajectinus (Traj 1374, c. 1595) manuscript tradition, with Regius taking primacy although the differences between them are scant. As citing the foliation in the body of the text would further clutter the page, I have opted to do so in footnotes. Faulkes's edition is confirmed as secure. Hopefully my iteration of this exercise spares future scholars similar efforts. On the relationship between Regius, Trajectinus, and the rogue Uppsala Edda, see Faulkes 1988, xxix-xxxiii. 
Muspellssynir. But the gods do not do this, at least in part because although the giants will eventually destroy them, they use the giants for labour. The goddess Gefjun relies on her half-giantish sons to pull her plough: 'hon tók fóra øxn norðan ór Jọtunheimum, en pat váru synir jọtuns ok hennar, ok setti pá fyrir plóg' (Snorri Sturluson in Faulkes 1988, 7) (she took four oxen from the north, out of the Giantlands, but they were the sons she had with a giant, and she put them before the plough). ${ }^{6}$ When Hymir has to go on a fishing expedition, he takes the giant Hymir with him as a servant. If we think of the case of the master builder, we will see that giant labour is even required to construct fortifications to keep out the giants themselves.

Do the Æsir have some sort of ideological mechanism for justifying this regime of exploitation? As noted by Bhabha, historically such arrangements have been underwritten by racism. Snorri's age was yet to discover 'race' in the Enlightenment sense, though medieval Christendom was capable of producing relatively sophisticated attitudes justifying violence towards and exploitation of ethnically different populations. For example, looking eastwards, Latin Christendom did not always view the Saracens as souls to be saved, but sometimes as enemies to be eradicated. These two alternatively configured attitudes to Islam are lucidly reflected in Old Norse literature, where, speaking very generally, a serkr (Saracen) is usually a man with whom one can have a conversation, whose body resembles that of a Scandinavian, and who is occasionally capable of chivalry (Sverrir Jakobsson 2016, 232-36). A blamadr, on the other hand, tends to be a dark-skinned, animalistic or even demonic creature, who usually has to be killed in combat (Cole 2015, 26-28). Of course, there are several exceptions to this generalization. As Sverrir Jakobsson has observed, there is one Old Norse account of missionizing to blamenn, and in the later lygisögur the blámadr can be quite erudite and charming $(2016,217-18)$. It has been suggested that some of the characters in Snorri's vivid subcreation are inspired by just such thirteenthcentury racial tropes concerning blámenn, Saracens, and Jews (Cole 2015, 28-32; 2017, 243-68).

However, in the general dynamic between Æsir and giants, Snorri may well have been thinking of an analogue closer to home than Saracens or Jews. It has been suggested that Old Norse myth in part reflects the interests and lifestyles of the social elite of the Viking Age, parachronistically preserved in the literary endeavours of the 1200s (e.g. Clunies Ross 1994, 49-50). A natural corollary to this suggestion would be to offer a comparison between the violent exploitation of the giants by the Æsir, and of the various peoples of Northern Europe by the

${ }^{6}$ Codex Regius, fol. $1^{\mathrm{v}}$; Codex Trajectinus, fol. $2^{\mathrm{r}}$. 
Vikings (e.g. Mundal 1996, 104-05, 111-13; Zachrisson 2008, 36).7 Of all the victims of the Vikings, the Sámi and Finns naturally suggest themselves as having similarities to the giants: indigenous people, with a land rather than a sea border connecting them to their oppressors, forced to pay tribute and pressured away from their ancestral lands. Indeed, it has been suggested that Skaði, with her skis and hunting prowess, is supposed to be a Finnic figure, representing the indigenous pre-Germanic-speaking population of Scandinavia. Her husband. Njorðr, on the other hand, prefers to live in the coastal regions, of the sort where the majority of Norway's Germanic-speaking population lived during the Middle Ages (Bragg 2004, 85-86; Koht 1910, 1-16; Steinsland 2011b, 29).

The same ideology which assumed the right of Norwegians to demand tribute from - and exert authority over - Finnic-speakers was still in force in Snorri's days. As Else Mundal $(1996,98-99,109)$ notes, Sámi appear repeatedly in thirteenthand fourteenth-century sagas, and in Norwegian law codes from the same period. Of the many examples that could be chosen, Egils saga recommends itself first as it is a text that has sometimes been attributed to Snorri (Björn M. Ólsen 1905; Hallberg 1962; Torfi Tulinius 2014, passim, but esp. 211-15, 284-88). I consider the attribution conjectural at best, though the value of the text for our purposes regardless is neatly summarized by Torfi Tulinius 'if he did not compose it, the author or authors were certainly quite close to him in both time and space' $(2014,1)$. It contains a description of the dynamic between Norse-speakers and Finnic-speakers that exhibits Æsirist undertones. From chapters 7-14 in the saga, the author details the practice of travelling northwards on a Finnferf (journey to the Finns) in order to exact Finnskattr (taxation of the Finns), or to have the right of Finnkaup (liberty to trade with the Finns). To orientate his audience, the author of Egils saga provides a potted geography of where the various Finnicspeaking peoples live.

Finnmǫrk er stórliga víð; gengr haf fyrir vestan ok par af firðir stórir, svá ok fyrir norðan ok allt austr um; en fyrir sunnan er Nóregr, ok tekr mǫrkin náliga allt it efra suðr, svá sem Hálogaland it ýtra. En austr frá Naumudal er Jamtaland, ok pá Helsingjaland ok pá Kvenland, pá Finnland, pá Kirjálaland; en Finnmǫrk liggr fyrir ofan pessi oll lọnd ok eru víða fjallbyggðir upp á mọrkina, sumt í dali, en sumt með vǫtnum. Á Finnmǫrk eru vọtn furðuliga stór ok par með vǫtnunum marklǫnd stór, en há fjǫll liggja eptir endilangri mǫrkinni, ok eru pat kallaðir Kilir. (Egils saga Skalla-Grímssonar in Sigurður Nordal 1933, 36)

${ }^{7}$ Zachrisson inverts the model, suggesting that mythology about giants shaped views about Finnic-speakers. The reality may have been more dialectic. 
(Finnmark is very wide. The sea runs from the west and adjoining it there are large fjords. It is the same way to the north and all the way to the east. And Norway is to the south, and the borderlands encompass nearly all the south, just like outer Hålogaland. And east from Numedal comes Jämtland, and then Hälsingland and then Kvenland, then Finland, then Karelia. And Finnmark sits atop all these countries and there are huge mountainous counties up in the marches, some [counties] in the valleys, and some alongside the lakes. In Finnmark there are very large lakes and next to the lakes large borderlands, and tall mountains run from one end of the marches to the other, which are called Kjølen.)

Like Jotunheimar, the land of the Sámi is depicted as hemmed in by the sea. As Lindow says of Jotunheimar, the territory inhabited by the Sámi also seems to be largely undesirable: mountains, lakes, and deserted marches (Lindow 2001, 206). Assuming for caution's sake that Egils saga was not penned by Snorri, stereotypes associated with Finnic-speakers can also be found in more secure locations inside the Snorronic oeuvre. In his Ynglinga saga, the king Vanlandi marries a Sámi girl by the name of Drífa, daughter of Snjár ${ }^{8}$ inn gamli (the Old). When Vanlandi leaves Sápmi and does not return, Drífa engages a witch named Hulð to bring him back. Though he is some six hundred miles southward in Uppsala, Vanlandi is suddenly siezed with a burning desire to return to Drifa's side (alas, the magic is too strong, and he is trampled to death by an invisible horse that no-one else can see while he dreams - a literal nightmare: Snorri Sturluson in Bjarni Aðalbjarnarson 1941, 28-29). Snorri returns to this theme in his Haralds saga ins hárfagra (c. 1220s-30s). Here, he offers his version of the tale of Snæfriðr, a Sámi woman who supposedly bewitched the semi-legendary king Haraldr hárfagri:

En Svási bað bera eigi at síðr annat sinn ørendit ok kvað sik vera pann Finninn, er konungr hafði játat at setja gamma sinn par annan veg brekkunnar par. En konungr gekk út ok varð honum pess jázi at fara heim með honum ok gekk yfir brekkuna með áeggjan sumra sinna manna, pótt sumir letti. Par stóð upp Snæfríðr, dóttir Svása, kvinna fríðust, ok byrlaði konungi ker fullt mjaðar, en hann tók allt saman ok họnd hennar, ok pegar var sem eldshiti kvæmi í hǫrund hans ok vildi pegar hafa <samræði við hana> á peirri nótt. En Svási sagði, at pat myndi eigi vera nema at honum nauðgum, nema konungr festi hana ok fengi at logum, en konungr festi Snæfríði ok fekk ok unni svá með œrslum, at ríki sitt ok allt pat, er honum byrjaði, pá fyrir lét hann. (Snorri Sturluson in Bjarni Aðalbjarnarson 1941, 126)

${ }^{8}$ As is common for names attached to Finnic-speakers, the name has an Arctic connotation, in this case from snjór (snow). Drifa is etymologically related to 'snow drift'. Snæfríðr is 'snow beauty'. Hulð is less clear, though the name has been suggested to be giantish (McKinnell 2014, 43; Cleasby and Vigfússon 1874, 292). It would be most straightforward to propose an etymology related to at hylja (to hide, conceal, especially with magic), and by extension the noun hulda. 
(But nonetheless Svási asked his message to be brought in again, and declared himself to be the same Finn whom the king had permitted to pitch his tent on the other side of the brook. And the king went out and gave him an agreement to accompany him home, and he crossed the brook with the encouragement of some of his men, although some refrained. Then Snæfrír stood up, the daughter of Svási, most beautiful of women, and poured the king a full vessel of mead, and the king touched both at the same time, the vessel and her hand, and at once it was as if the heat of a fire came upon his skin, and at once he wished to have sex with her on that very night. But Svási said that it wouldn't happen by any means unless the king married her and was lawfully engaged to her. And the king proposed to Snæfriðr and was married to her, and loved her with such madness that he forgot all his kingdom and all he was supposed to watch over.)

More than one prejudice may be at work in this passage. ${ }^{9}$ The first is the association of Sámi with magic, which is a staple of Old Norse literature (DeAngelo 2010, 258-62; Mitchell 2011, 54-55, 106-07). Haraldr's uncontrollable attraction to Snæfrír is induced by her father's sorcery, but Snorri makes it clear that she was already to be considered highly desirable (kvinna fríust). It may be that Snorri intended her to be understood simply as a Sámi who happened to be strikingly beautiful - but it is also plausible that she is representative of a type. That is to say, her Sámi-ness can be understood as being intimately connected to her attractiveness: the alluring Sámi, an exotic Other fetishized by the male gaze. As Sandra Ballif Straubhaar has shown, Finnic-speaking women were sometimes described as repellent or even monstrous (2001, 119-21). However, there is no reason why two types could not co-exist in Snorri's mind, or the mind of any other thirteenth-century Old Norse speaker: 1) the Finnic-speaker as inaccessible, bewitching, and therefore desirable, and 2) the Finnic-speaker as sub-human, and therefore loathsome. Examples from other times and places of 'racial fetishism' attest to the possibility of self-contradictory stereotypes being attached to female members of an ethnic minority (Hook 2005, 707-08; Lee 2001, 76-77; most rigorously: Zheng 2016, 400-06). The stereotype of the desirable, sexually submissive Asian woman does not preclude the stereotype of the bucktoothed, wizened, nagging Asian woman. The caricature of the overly irate African-American woman shares the racist's mental landscape with that of the sexually insatiable African-American woman. In France, the beurette (Verlan

${ }^{9}$ Meylan points out a stunning analogue between this tale and a Castilian tradition concerning the infatuation of King Alfonso VIII (r. 1158-1215) with a Jewish woman (Meylan 2018, esp. 141-48). It was brought to my attention too late to be included in my discussion, but in this case the similarities between the Jew-in-Spain and Finnr-in-Norway as narrative archetypes are arresting. 
for arabette) is a profoundly sexualized fantasy of Muslim women, which emerged at around the same time that French society became fixated on the stereotype of the violent, radical Islamic Frenchwoman (Fassin and Trachman 2013, 199-217). Snæfrídr, and to a lesser extent Drífa, may represent similarly colonially inflected sexual stereotypes of which Snorri knew, or possibly that he even entertained in his own fantasies.

The parallel between Norwegian-Sámi colonialism and Æsir-jottnar colonialism is further illuminated when Snorri's story of Snæfríor in Haralds saga ins hárfagra is compared to his retelling of the Gerðr myth in the Edda. (Strictly speaking, Freyr is of the Vanir, though in Snorra Edda the Vanir function mostly as a sub-tribe of the Æsir - once different and perhaps not always as privileged as the 'pedigree' Æsir, but there is little doubt as to where their loyalties lie in contrast to the giants. ${ }^{10}$ In the original Eddic poem Skirnismál, the god Freyr orders his messenger, Skírnir, to threaten Gerðr into yielding to his sexual desires. This is very much a rape, with Skírnir terrorising Gerðr with threats towards her father, and graphic descriptions of the perverted, frustrated nymphomaniac creature into which Gerðr will be magically transformed if she refuses. Snorri's account still retains troubling undertones, but otherwise he attempts to remove some of the more noxious elements of the story. As Carolyne Larrington notes, 'Snorri suppresses the threats and curse entirely and regularizes the relationship with marriage and a child' (1992 [1993], 6):

Gymir hét maðr, en kona hans Aurboða. Hon var bergrisa ættar. Dóttir peira er Gerðr er allra kvenna er fegrst. Pat var einn dag er Freyr hafði gengit í Hliðskjálf ok sá of heima alla, en er hann leit í norðrætt pá sá hann á einum bo mikit hús ok fagrt, ok til pess húss gekk kona, ok er hon tok upp họndum ok lauk hurð fyrir sér pá lýsti af họndum hennar bæði í lopt ok á log, ok allir heimar birtusk af hennar. Ok svá hefndi honum pat mikla mikillæti er hann hafði sezk í pat helga sæti at hann gekk í braut fullr af harmi. Ok er hann kom heim, mælti hann ekki, hvárki svaf hann né drakk; engi porði ok krefja hann orða. (Snorri Sturluson in Faulkes 1988, 30-31) ${ }^{11}$

(There was a man called Gymir, and his wife was called Aurboða. She was of the race of the mountain-giants. Their daughter is Gerðr, who is the most beautiful of all women. One day Freyr had gone up to Hliðskjálf and looked over all the worlds, and when he looked in the northern direction he saw in a certain settlement a large and beautiful house, and a woman was walking to this house, and as she raised her

${ }^{10}$ Clunies Ross suggests that Vanir males have a preference for giantish females (Clunies Ross 1994, 97) though we must be careful that in Snorra Edda it is the female, giantish Skaði who chooses the Vanir Njorðr — the match was not his idea.

${ }^{11}$ Codex Regius, fol. $9^{\mathrm{r}}$; Codex Trajectinus, fol. $9^{\mathrm{v}}$. 
arms to open the door her arms shone both into the air and onto the water, and all the worlds were illuminated by her. And so he was repaid for the great arrogance of sitting in the holy seat, that he went away full of sorrow. And when he came home, he did not speak, neither did he sleep nor drink. ${ }^{12}$ Nobody dared to ask a word of him.)

There are some contrasts between Snorri’s Snæfríðr and Gerðr episodes. Snæfríðr's father, Svási, actively seeks to bewitch Haraldr (it is not recorded how aware or enthused Snæfriðr herself was about this plot). In the Eddic poem, Gerðr's father, Gymir, is understandably opposed to his daughter's abduction. Although the narrative voice of Snorra Edda is tight-lipped on how Gymir felt, Snorri does not signal that Freyr's lust was in any way a result of conjuring from Gymir's quarter. However, there are also some unignorable similarities. Firstly, there is a verbal parallel: Snæfríðr is 'kvinna fríðust' (most beautiful of women) while Gerðr is 'allra kvenna [ ] fegrst' (of all women most beautiful). There are also thematic parallels: Haraldr is so monomaniacally smitten that he ceases to conduct sufficiently his office as king. Freyr also breaks down, and he is so obsessed that he gives his sword to Skírnir in return for his help in wooing Gerðr. ${ }^{13}$ In doing so, he neglects his duty to fight the giant Beli at Ragnarøkr. It is a further example of Óðinn's untrustworthiness, that he ineptly tries to conceal this shortcoming: 'Lítit mark var pá at er peir Beli hittusk. Drepa mátti Freyr með hendi sinni. Verða mun pat er Frey mun pykkja verr við koma er hann missir sverðsins pá er Muspells synir fara ok herja' (Snorri Sturluson in Faulkes 1988, 31-32) ${ }^{14}$ (It was of little significance when he and Beli met. Freyr could have killed him with his bare hands. It will come to be that Freyr will think it the worse that he lacks the sword when the sons of Muspell go to war.) - it can't be that it is both no obstacle to Freyr, and that he will regret it. A similarity between Gerðr's and Snæfríðr's situations has also been proposed by Lars Lönnroth:

En god parallell till denna förälskelse synes vara i Snöfrid såsom den skildras i Ágrip och Heimskringla. Också i det fallet gäller förälskelsen en kvinna som enligt

12 There is a parallel here with Tristrams saga ok Ísondar (c. 1226), which says this of Tristram after he first meets the queen: 'Enskis fýsti hann svá í pessari veröldu, hvárki matar né drykkjar né annarra hluta, nema at sjá ok tala við Ísönd dróttningu' (He desired nothing in this world, neither food nor drink nor anything, except to see and speak with Queen Ísond) (Kalinke 1999, 218). I assume this similarity has been reported before but have not been able to locate a source if so.

${ }^{13}$ It can only be construed as 'wooing' in Snorri's subcreation, of course. In Skirnismál it is nothing less than rape.

${ }^{14}$ Codex Regius, fol. 9 ${ }^{\mathrm{v}}$; Codex Trajectinus, fol. $10^{\mathrm{r}}$. 
gängse normer inte kunde accepteras som äktenskapspartner (Snöfrid var dotter till en lappsk trollkarl), och passionens plötslighet är ett vittnesbörd om desse övernaturliga, demoniska ursprung. Fördömelsen av den åtrådda kvinnan är i fallet Snöfrid mer explicit, men också Gerd framställes som demonisk i egenskap av invånare i 'det andra landet', här lika med Jättarnas land. Därför blir det legitimt att bruka den för övrigt olagliga kärleksmagin för at vinna henna. Hon besegras så att säga med sin egen medicin. (Lönnroth 1977, 169, emphasis in original)

(A good parallel for the falling in love [of Freyr with Gerðr] would appear to be the case of Snæfrír, as it is related in Agrip and Heimskringla. This case too concerns falling in love with a woman who according to contemporary norms could not be accepted as a marriage partner (Snæfrídr was the daughter of a Lappish magician), and the suddenness of the passion is a testament to its supernatural, diabolical origins. In the case of Snæfrírr, the condemnation of the desired woman is more explicit, but Gerðr is also depicted as diabolical in her quality as an inhabitant of 'the Other country', in this case the land of the giants. This is why it is legitimate to use otherwise illegal love-magic to win her. She gets, so to speak, a taste of her own medicine.)

It must be remembered that Lönnroth is discussing the Eddic version of the Gerðr myth, not the Snorronic version, and that he is summarizing Skírnir's thought processes rather than his own. Certainly, the reading that Gerðr in any way bears a responsibility for Freyr's desire is objectionable, as Larrington has shown (1992 $[1993], 6)$. To me, it seems that the chief similarity between the two situations is actually to be found at the delicate nexus between sexual desire (the personal) and ideology (the political). Haraldr looks upon Snæfríor with a male, colonial, racially fetishizing gaze. The madness of his desire may be magically induced, but the desire itself is a product of the colonial experience. He wants her because she belongs to a minority to which he has attached certain superstitions, and over which he feels he has a certain degree of pre-eminence. Similarly, Freyr wants Gerðr not in spite of her giantness, but because of it. His world view, like that of any of the other male gods, includes a feeling that he is entitled to her giantish body, and also that in some way her body - as opposed to other bodies - would be particularly sexually gratifying because it is giantish. This is an example of the pervasiveness of colonialism. On a macro-level, Pórr's hammer crushes the skulls of giant men. On a micro-level, Freyr is driven to distraction by his desire to conquer the sexuality of giant women.

The relationship of the Æsir to the giants is colonial in multiple spheres. They dominate them technologically, control their land, but they also require their labour (see also Cole forthcoming), as one finds in the myth of the giantish master builder, Gefun's giantish bulls, and as we will later see in the case of Pórr taking Hymir on his fishing expedition. Moreover, the Æsir males expect to 
have access to giant-women, but they are consistently horrified by the thought that giant males might have access to Æsir women (Clunies Ross 1994, 57, 97; Lindow 1997, 15-16). When they are forced by a peace accord to let a giantwoman, Skaði, marry a male god, they trick her so that she does not pick Baldr, her preferred choice and the most attractive of the Æsir, but instead chooses Njorrðr, who is in fact not one of the Æsir but one of the Vanir, a tribe defeated in war and assimilated by the Æsir. ${ }^{15}$ The giants are depicted as constantly slavering over Freyja, whom the Æsir have a responsibility to protect from their advances. It is presented as uncontroversial that the male god Freyr can have sexual relations with the giantess Gerðr. Similarly, Pórr has an extramarital liaison with a giantess named Járnsaxa. The resultant offspring, Magni, is raised as a good member of the Æsir. But when the male giant Fárbauti has sex with the apparently non-giant female Laufey, the resultant offspring is Loki. Though raised amongst the Æsir, Loki is a devious figure whose own erotic encounters with the giantess Angrboða apparently re-concentrates his giant heritage, resulting in the monstrous brood of the wolf Fenrir, the serpent Jomungandr, and the death-deity Hel. By way of analogy, we might observe that this is a sort of thinking which is not altogether remote from colonial sexual regimes such as those of the American south. As Ida B. Wells wrote in 1892:

the misceg[e]nation laws of the South only operate against the legitimate union of the races; they leave the white man free to seduce all the colored girls he can, but it is death to the colored man who yields to the force and advances of a similar attraction in white women (Wells 1892, 53-54).

I certainly do not intend to equate the actual historic suffering of real populations with the imaginary sufferings of mythical tribes. But I would propose that such analogies can be illuminating for understanding the psychology of the Æsir, as Snorri depicts them.

\section{Reactionary Elements: Decline and Blame}

Despite the ready interpretation that it is really the Æsir who victimize the giants, rather than the other way round, the Æsir themselves entertain the feeling that their world is in a state of decay, and that it is migrants from Giantland who are to blame for their supposed decline. Óðinn explains that:

${ }^{15}$ Historically the war between the Æsir and the Vanir has also been viewed as a memory of some long-lost, actual religious conflict. On this view, now outdated, see Turville-Petre 1964, 156-62. 
'Par næst gerðu peir pat at peir logðu afla ok par til gerðu peir hamar ok tọng ok steðja ok paðan af ọll tól ǫnnur. Ok pví næst smíðuðu peir málm ok stein ok tré, ok svá gnógliga pann málm er gull heitir at oll búsgogn ok ǫll reiðigogn hǫfou peir af gulli, ok er sú ǫld ko lluð gullaldr, áðr en spiltisk af tilkvámu kvennanna. Pær kómu ór Jǫtunheimum.' (Snorri Sturluson in Faulkes 1988, 15) ${ }^{16}$

(Next they did so, that they made forges and so they made hammers and tongs and anvils, and from those all other tools. And next they smithed metal and stone and wood, and so abundantly [they made] that metal which is called 'gold' that all their fittings and utensils were made from gold, and this age was called the Golden Age, before it was spoiled by the arrival of those women. They came from the Giantlands.)

Following James Barr (1974), and later Lowell Handy (1994, 136-39), who were writing about the case of Canaanite myth, we might call this episode a 'technogony'. It is a subset of mythological material which explains how certain tools were created, which give the gods a technological advantage that legitimates their supremacy over their foes. The description of this epoch as a gullaldr (Golden Age) is probably Snorri's own idea, rather than a concept in Norse myth that existed in the minds of others before the 1220s. It is conceivable that gullaldr originates as a calque of Latin aetas aurea, e.g. from Ovid's Metamorphoses, although Ovid's 'Golden Age' is more peaceful and not so technologically advanced: 'Aurea prima sata est aetas, quae vindice nullo, | sponte sua, sine lege fidem rectumque colebat' (Miller 1916,8) (The first age is golden, where none commanded, | [and] of one's own accord, without law, [one] was faithful and did the right thing).

Like most 'Golden Ages', things were probably not really as good as they were supposed to be. The gullaldr might have been a time when the Æsir were wealthy, but their prosperity was founded on violence. The giant patriarch Ymir had been killed, his body used to create fortifications to keep his descendants out of Miðgarðr, and all the Rime-Giants apart from one named Bergelmir and his household had been drowned by the ocean of blood that flowed out of Ymir's corpse. (Bergelmir and his wife survived by floating on a giant wooden box, and then went on to repopulate the Giantlands, this detail being drawn from Genesis's flood narrative, see for example Tolley 1997, 71-73.) Perhaps the reason Óðinn tries to convince us that this was a 'Golden Age' is not because he truly believes in the glory of Ásgarðr, but because he truly believes in the nefariousness of giants. The point is not that Ásgarðr was ever that great, but rather that the giants are what is standing between Ásgarðr and greatness. By blaming the giants for

${ }^{16}$ Codex Regius, fol. $4^{\mathrm{r}}$; Codex Trajectinus, fol. $5^{\mathrm{r}}$. 
Ásgarðr's problems, any ongoing acts of violence and marginalization against them become justified. This is reactionary politics par excellence: a future of cruelty disguised as a return to a past that never actually existed.

Despite Óðinn's rhetoric, it is doubtful that he or any of the other Æsir are seriously engaged in a project to return to the gullaldr. As Abram notes $(2019,135-138)$ when the council of the Æsir meet to discuss what to do about the giant immigrants, their response is to reminisce about the creation of the dwarves, though Abram is more forgiving than I am about how well-reasoned this strategy may be. This commitment to discussing a historic problem, while remaining ineffectual on actually addressing it, calls to mind Roger Griffin's theory of 'palingenetic myth'. According to Griffin (1991, 32-36), fascist ideologies are predicated on an obsession with rebirth, particularly through turbulent events which will leave humanity in an era that simultaneously recalls an ideal time in the past, and promises a new, utopian age. (As an aside, Griffin notes that the Eternal Return by Mircea Eliade, which has exerted some influence on Old Norse mythography, can be read as an expression of the fascist preoccupation with palingenesis: Griffin 1991, 31,33, 173.) The term 'palingenetic myth' seems particularly appropriate for describing the Æsir's long-term policy objectives (or lack thereof). They lament the incursion of the giant-women, and they look forward to an epic battle in which they will themselves be destroyed, but make no effective moves to regain their supposed glory. They simply perpetrate more and more violence against their giantish neighbours. The irony is that Óðinn knows a rebirth of sorts is coming: the world will indeed be born again after Ragnarøkr, but it will be without him, and without Æsirism (we shall return to this point in the conclusion).

It is fitting that we do not really know who exactly the three ruinous giantesses were supposed to be. It is probable that Snorri didn't either, and he was simply backforming from an equally cryptic verse in Voluspá: 'Teflðu í túni, | teitir váro, | var peim vettergis | vant ór gulli, | unz prjár kvómu | pursa meyjar, | ámáttkar mjọk | ór jọtunheimum' (Eddukveði in Jónas Kristjánsson and Vésteinn Ólason 2014, 293) (They played chess | in their settlements | they were joyful | there was never any | want for gold | until three came, | maidens of the giants | very strong | from the Giantlands). By extension, Óðinn himself doesn't really know. The leader of the Æsir knows how to propagandize in a post-truth political climate. The term 'post-truth' here is particularly appropriate. It is more than simply 'lying'. Rather, it refers to the phenomenon where so many contradictory accounts of a particular event are given that it becomes impossible to entangle what is authentic from what has been consciously adulterated. The truth may well be there amongst all the differing reports, but it is lost like a needle in a haystack. 
A pronouncement by Hannah Arendt on totalitarian regimes, quoted frequently in our own days, describes the situation thus:

a lying government has constantly to rewrite its own history. On the receiving end you get not only one lie-a lie which you could go on for the rest of your days-but you get a great number of lies, depending on how the political wind blows. And a people that no longer can believe anything cannot make up its mind. It is deprived not only of its capacity to act but also of its capacity to think and to judge. And with such a people you can then do what you please. (Arendt 1978, 18)

In light of Arendt's observation, one wonders if the fascist and Odinic attitudes to truth might have a great deal in common. To take the example of the origin myth of the Æsir, the Edda as a whole contains probably four different accounts, of varying degrees of mutual agreement. The prologue offers the allusion with Troy, stating that Pórr was identical with a Thracian hero called Tror and that Pórr/Tror was the great-great-great-great-great-great-great-great-great-greatgreat-great-great-great-great-great-great-great-grandfather of Óðinn (no. 1). ${ }^{17}$ The narrative frame of Gylfaginning also adopts a Trojan tone, but instead states that Pórr was actually Hector (no. 2). ${ }^{18}$ Then the reply given by Óðinn/Hár to the question 'Hvat var upphaf ? Eða hversu hófsk? Eða hvat var áðr?'(Snorri Sturluson in Faulkes 1988, 9) (What was the beginning? Or how did things start? Or what was before?) is a totally different story, where the gods are descended from a humanoid being who emerged from a block of ice (no. 3). ${ }^{19}$ In Gylfaginning, the narrative frame revolves around the gods convincing King Gylfi to worship them, but in Skáldskaparmál a different frame is used, where the gods must instead convince a magician named either Ægir or Hlér. There, Snorri advises us that the Æsir falsified (folsudu) their story and that we should instead listen to the definitive account which he then provides (no. 4).$^{20}$ According to no. 4, Óðinn is supposed to be King Priam of Troy, and not a descendant of Pórr, thus vitiating story no. 1 . Sufficiently scanty detail is given about no. 2 that it may well be fully

17 Snorri Sturluson in Faulkes 1988, 4-5; Codex Trajectinus, fol. $1^{\mathrm{r}-\mathrm{v}}$; Codex Regius is missing the first folio of the prologue.

18 Snorri Sturluson in Faulkes 1988, 55; Codex Regius, fol. 17', 'ector' is written above 'PoR', in what to me seems to be the same hand as the scribe who wrote the rest of the page. Codex Trajectinus fol. $18^{v}$ has simply 'ector', with a side note in what seems to me a different hand, stating 'Hector affapor N.B. Vlÿßes heitir Loke' (Hector [= ] Ásapórr. N.B. Ulysses is called Loki). The entire section is absent in the Uppsala Edda.

${ }^{19}$ Snorri Sturluson in Faulkes 1988, 9-12; Codex Regius, fols $2^{\mathrm{r}}-3^{\mathrm{v}}$; Codex Trajectinus, fols $2^{\mathrm{v}}-4^{\mathrm{r}}$.

${ }^{20}$ Snorri Sturluson in Faulkes 1998, 5; Codex Regius, fol. 20 ; Codex Trajectinus, fol. $20^{\mathrm{v}}$. 
compatible with no. 4. However, no. 4 itself explicitly recommends comparison with no. 1. Snorri’s narrative voice in Skáldskaparmál advises:

En eigi skulu kristnir menn trúa á heiðin goð ok eigi á sannyndi pessar sagnar annan veg en svá sem hér finnsk í upphafi bókar er sagt er frá atburðum peim er mannfólkit viltisk frá réttri trú, ok pá næst frá Tyrkjum, hvernig Asiamenn peir er Æsir eru kallaðir fọlsuðu frásagnir pær frá peim tíðindum er gerðusk í Troju til pess at landfólkit skyldi trúa pá guð vera. (Snorri Sturluson in Faulkes 1998, 5)

(And Christians should not believe in pagan gods and not in the truth of these stories in any other way than is found here in the beginning of the book, where it is told of those events when humanity lost its way from the correct faith, and then concerning the Turks, how the men of Asia who are called the Æsir falsified the story concerning those events which happened in Troy so that the population should believe them to be God.)

By 'upphafi bókar' (beginning of the book) Snorri must mean the Edda as a whole, not Skáldskaparmál in particular, as it is only the prologue that contains an explicit story of how 'humanity lost its way from the correct faith.' Origin story no. 3 is at odds with all the other stories. Why such confusion? In part - perhaps in entirety - it is because Snorri knew multiple stories, or that Snorri came up with multiple variations on a theme and lost track of the finer details. But even if Snorri's shortcomings are entirely to blame for the various inconsistencies in the $E d d a$, the shifting sands upon which the Æsir build their stories still create a post-truth atmosphere. Gylfi is no dullard. Snorri describes him as 'maðr vitr ok fjolkunnigr' (Snorri Sturluson in Faulkes 1988, 7) (a wise man, gifted in magic). ${ }^{21}$ Yet he still eventually falls for Óðinn's lies. Arendt prompts the reading that, as the Æsir 'rewrite their own history', Gylfi's undoing is not that Óðinn tells only one lie very well, but that he tells a great number of lies, until Gylfi can no longer grasp at the skeins of truth.

Keeping a focus on the post-Viking-Age context of Snorri's Edda, it is worth noting that Scandinavians were apparently viewing their various Finnic neighbours in terms that chime with Æsirism well into the late Middle Ages. A particularly flagrant manufacturing of hollow pretexts for violence can be found in a letter from King Christian I of Denmark-Norway (r. 1448-64) to King Alfonso the Magnanimous of Aragon (r. 1416-58), dated 27 May 1456. ${ }^{22}$ In the following, King Christian attempts to draw a parallel between his subjugation

${ }^{21}$ Codex Regius, fol. $1^{\mathrm{v}}$; Codex Trajectinus, fol. $2^{\mathrm{r}}$.

${ }^{22}$ Given that King Christian was eight years old, it is reasonable to assume that his counsellors took the initiative in composing the letter. 
of the Sámi and King Alfonso's engagements with the Muslims of the emirate of Granada to the south, and the Ottoman Empire to the east. Whether through ignorance or deliberate rhetorical slyness, Christian depicts the Sámi alongside a somewhat nondescript list of people who are supposedly pressing threats to Christendom:

aperiamus fiducia qvantis in hiis aqvilonaribus angulis paganorum insultibus angemur. Cum nobis cum Tartaris, Cumanitis, Erpionibus, Manbris, et Lapis, ferocissimis nationibus continua pugna concrescat, extemplo bellicis contra eos exercitemur congressibus. Nam cum regnum nostrum Norvegie vadis et terminis extendatur latissimis $[\ldots]$ contraqve nostros gentiles ad invicem. (Bugge 1913, 1008-09)

(We disclose how greatly in this northern corner we are distressed by the attacks of the pagans. Together with us you continue to fight against the Tartars, Cumans, Erpionites [Erzya Mordvins?], Manbrites [Mansi?] and Lapps, ${ }^{23}$ the most ferocious nations, joining arms immediately against them at the sound of a war-trumpet. For example, together with our kingdom of Norway you go and extend the borders [of Christendom?] most widely [...] as well as against our own non-believers.)

In King Christian's letter, just as in Óðinn's account of the death of Ymir, violence is justified on the assertion that 'we were attacked first' - even though in reality the supposedly injured party is extracting tribute from the supposed aggressor. There are considerable caveats to be made here, of course. A fifteenth-century letter can be no indicator of specific Realpolitik in the thirteenth century. But this general variety of rhetoric would have been recognizable to Snorri, because it is essentially timeless: the protestation from a hegemonic power that it is in fact a victim, and that its violence is therefore a form of self-defence. A basic sense of morality will prevent most people from answering a call to butcher people who are advertised as being powerless and harmless. If one tells people that they are under attack from an enemy who is in some regard effective, on the other hand, one will find many more willing recruits. The myth of the blood-libel or the well-poisoning provided the pretext for the annihilation of the Jews of medieval Europe. Myths of the Rothschilds or the vast Bolshevik conspiracy did the same for modern Jews. In King Christian's letter, the image of a Sámi alliance with the Tartars and Cumans guided readers away from the view of the Sámi as underdogs, and towards the idea of the Sámi as a threat to be dealt with through martial force. Ymir's supposed bellicosity and the incursion of the three giant women

23 The politically correct term today would of course be Sámi, but the Latin here is Lapis, and it is certain that the original author of the letter wished to communicate a chauvinistic tone with little regard for the dignity of indigenous peoples. 
can be fitted into the same dismal genealogy of persecuted minorities recast as predatory malefactors.

\section{The Prophet Motive? Blindness and Fatalism in Capitalism and Asirism}

David Graeber has noted that certain ideologies entail mad dreams of the futures they promise $(2015,142)$. For example, there was a grandeur of scale in the dreams of the Soviet Union: the promise of socialist colonies amongst the stars, hundreds of years into the future. Even the horrid nightmares of the Third Reich offered a vision dizzying in magnitude, cruelty, and the magnitude of its cruelty: a racially homogeneous empire from the Urals to the Low Countries, a Großgermanisches Reich Deutscher Nation, with a futuristic global capital, the Welthauptstadt Germania, brimming with the plunder of conquered nations. The utopian potential of medieval political ideologies tended to be limited by the Christian necessity of belief in the apocalypse. In orthodox thought, an eventual paradise was guaranteed, but it was bound up with the literal 'hell on earth' foretold in Revelations. However, even given these limitations, utopian thinking was not impossible for the medieval mind. Schismatic movements frequently emerged, promising to usher in the end of days (Cohn 1970, 41-52). In the case of the Taborites of fourteenth-century Bohemia, their promise was, to quote Norman Cohn: 'a return to the lost anarcho-communist order. Taxes, dues, rents were to be abolished and so was private property of all kinds. There was to be no human authority of any sort' $(1970,215)$.

If these are the dreams of socialism, fascism, and millenarianism, what are the dreams of Æsirism? Appropriately, the gods see their ultimate destiny in dreams. But here there are no bold fantasies. The events that will cascade into Ragnarøkr begin with Baldr seeking comfort from the other gods, persistently plagued by nightmares: 'En pat er upphaf pessar sọgu at Baldr inn góða dreymði drauma stóra ok hættliga um liff sitt' (Snorri Sturluson in Faulkes 1988, 45) (And it is the beginning of this story, that Baldr the Good dreamed great and horrifying dreams about his life). ${ }^{24}$ The Æsir, it seems, do not look forward to a glorious future. They do not conceive of their political order as a way to bring about utopia. Rather, it is an impermanent bulwark against forces that will ultimately destroy them. Æsirism is conservative in that it can hope for nothing more than stasis. Æsirism is anti-utopian in that it entertains no dreams: only nightmares.

${ }^{24}$ Codex Regius, fol. 14v ; Codex Trajectinus, fol. 15 . 
At the end of the world, the age-old enemies of the Æsir will finally get the upper hand. Led by Loki and the Muspellssynir (Sons of Muspell), a force of giants will charge across the Rainbow Bridge (Bifrost) and vanquish the Æsir. Yet it would be a mistake to think that there is something of the Bildungsroman about this narrative, where the giants are off accumulating their forces, and finally get their revenge through their own industry. The Muspellssynir may deliver the deathblow to the Æsir, but it is actually the Æsir who undo themselves. They make a series of consistently poor decisions which leave them ill-prepared to face their foes at Ragnarøkr. As we have seen, Freyr trades his sword to his messenger, Skírnir, in return for Skírnir's co-operation in threatening the giantess Gerðr into sexual relations with him. He is consequently unarmed in the final battle. Óðinn and the other Æsir refuse to kill Fenrir when they have the chance, because they do not want to defile the sacred spaces they have set up in their own honour. Óđinn himself explains that 'Svá mikils virðu goðin vé sín ok griðastaði at eigi vildu pau saurga pá með blóði úlfsins pótt svá segi spárnar at hann muni verða at bana Óðni' (Snorri Sturluson in Faulkes 1988, 29) (The gods so highly esteem their sacred groves and places of truce that they would not defile them with the wolf's blood, even though the prophecies say that he would be the death of Óðinn). ${ }^{25}$ This seems like a noble enough sentiment, although to my mind it smacks of false modesty. If piety really were the reason that the Æsir refused to prevent Ragnarøkr, then the principal hamartia of the gods would be that they were too honest, too faithful to their oaths, too committed to playing by the rules, etc. But as the story of the master builder shows, the gods are not at all opposed to breaking their promises and acting in deceptive, unjust ways. Indeed, when they bound Fenrir in the chains called Gleipnir, they also violated an agreement:

Úlfrinn segir: 'Ef pér bindið mik svá at ek fæk eigi leyst mik pá skollið pér svá at mér mun seint verða at taka af yðr hjálp. Ófúss em ek at láta petta band á mik leggja. En heldr en pér frýið mér hugar pá leggi einnhverr họnd sína í munn mér at veði at petta sé falslaust gert.' En hverr Âsanna sá til annars ok pótti nú vera tvau vandræði ok vildi engi sína họnd fram selja fyrr en Týr lét fram họnd sína hœgri ok leggr í munn úlfinum. En er úlfrinn spyrnir, pá harðnaði bandit, ok pví harðara er hann brauzk um, pví skarpara var bandit. Pá hlógu allir nema Týr. Hann lét họnd sína. (Snorri Sturluson in Faulkes 1988, 28-29) ${ }^{26}$

${ }^{25}$ Codex Regius, fol. $8^{\mathrm{v}}$; Codex Trajectinus, fol. $9^{\mathrm{r}}$.

${ }^{26}$ Codex Trajectinus, fols $8^{\mathrm{v}}-9^{\mathrm{r}}$ has 'vélalaust ok falslaust'. 
(The wolf says: 'If you tie me so that I cannot get free then you will betray me so that I won't be quick to seek your help again. I am reluctant to have these bonds put upon me. And instead of questioning my character then one of you should put their hand in my mouth as a deposit for if this has been done deceptively.' And each of the Æsir looked at each other and saw they had a couple of problems, and nobody wanted to offer their hand until Týr extended his right hand and put it in the wolf's mouth. And as the wolf struggled, the bonds became stronger, and it become stronger the more he fought, and the bonds cut more. Then everybody laughed except Týr. He lost his hand.)

As Jóhanna Katrín Friðríksdóttir $(2013,125)$ has pointed out, oath-breaking was considered a very serious transgression both in the mythological world depicted in the Poetic Edda and in Snorri's present in thirteenth-century Iceland. The law-code compendium Grágás takes a dim view of those who renege on a guarantee of safety: 'En pat eru log inoregi oc alla dansca tungo ef maðr pyrmir eigi griðom at sa maðr er utlager fyrir endi langan noreg fra. oc feR bæði er londom sinom oc lavsa fe. oc scal aldregi iland coma sipan' (Grágás in Vilhjálmur Finsen 1974, 205) (It is the law in Norway and all Norse-speaking countries that if one does not honour a truce, one is outlawed from one end of Norway to the other, and loses both their property and their chattels, and they shall never return to the country again). The Old Norwegian Homily Book (c. 1200) lists meinęidar (oaths taken in vain) as being amongst the cardinal sins (Indrebø 1966 [1931], 35). But on this occasion, the gods find it hilarious that they have committed an act of treachery - not to mention that one of their own has been seriously injured.

Exactly how grave the misdeeds of the Æsir were depends on how we reconstruct the legal praxis of Æsirism. How far were the norms of the gods in Snorri's imagination like those of medieval Scandinavians? John Lindow draws attention to the discussion of gridastadir in Old Norwegian law codes (the griðastadr (place of truce) being the reason why Óðinn claims the gods cannot act). The effect of a gridastadr is also given as the reason why Loki was not immediately killed for his use of Hǫðr as an unwitting assassin to kill Baldr. Óðinn relates that: '[Æsirnir] váru allir með einum hug til pess er unnit hafði verkit. En engi mátti hefna, par var svá mikill griðastaðr' (Snorri Sturluson in Faulkes 1988, 46) ([The Æsir] were all of one mind concerning who had done the deed. But none could take vengeance, because it was such a great place of truce there) ${ }^{27}$ On this occasion, Lindow observes:

${ }^{27}$ Codex Regius, fol. 15 ; Codex Trajectinus, fol. 15 . 
Snorri seems to combine aspects of both the Norwegian legal concept of the gridastadr, as an occasion of heightened sensitivity to misdeeds, and the Church concept of asylum, where none may be punished. Both of these influences would situate the sanctuary he imagines in the Middle Ages rather than in mythic prehistory. Indeed, his use of griðastadr looks like a rather feeble attempt to explain the lack of immediate vengeance when Baldr is struck down. (Lindow 1997, 133)

Lindow further provides a detailed and convincing explanation for his suggestion that the gridastadr was only a pretext for inaction in the case of killing Baldr. But let us keep our attention on the less discussed problem of the gridastadr in the binding of Fenrir. As Lindow $(1997,131)$ notes, the Old Norwegian Landslog (1274) and Bójarlog (1276) are the law codes which provide the fullest detail on when the condition of grið (truce, lit. 'domicile') should apply. A further text which warrants mention is found in the manuscript GKS 1154 fol., also known as the Codex Hardenbergianus. The manuscript contains a version of the Gulapingslog (1200-50) which has been spliced with material from the aforementioned younger Norwegian codes. The Landslog, Bójarlog, and the revised Gulapingslog all spring from the massive restructuring of Norwegian legislation undertaken by King Magnús lagabótir (the Law-Mender) Hákonarson (r. 1263-80). GKS 1154 presents a chapter on when a gridastaðr is in effect, apparently whether it is officially declared or not. The chapter which follows immediately afterwards concerns when it is right to place bonds on someone. These two areas of concern are of substantial importance in determining the rights and wrongs of the Fenrir scene:

Hér segir um griðastaði hversu halda skal: stinn í leiðangirs ferðum meðr konungi, ęða á pingum eða á stefnum fyrir logmanni, eða á fimmtar stefnum í gildum eða bruðlaupum [,] i jólagriðum eða sildfiski, skírdag ok um fram páskavika, at sjálfrétt eru grið í pessum stǫðum, ok pessum tímum [...] Um pat ęf maðr bindr mann: ollu útl’́gir ef peir pøygja binds frjálsan mann at ósynju gjaldi .v. merkir s[ilfrs] konungi, en inum fullrétti er bundinn var eftir tólf manna dómi. (General Law of the Gulathing in Flom 1937, 114-15, my normalization)

(Here is told of how places of truce shall be established: stringently in the case of assembling troops on the way to the king, or in councils or in arranged meetings before a judge, or on a valid deposition before a court or at weddings, during Christmas truces or during herring fishing, holy days and Maundy Thursday and throughout the week of Easter, that there is tacitly sanctuary in these places and these times [...] Concerning if one binds somebody: all are outlawed if they tie bonds upon a free man secretly, paying five marks of silver to the king, and [are to pay the same amount to the same recipient] for the grave offence of one who was bound according the judgement of twelve men [!]) 
By the logic of GKS 1154, the Æsir would have implicitly offered and then violated grid, because it seems they are at council (ping) when they meet Fenrir: all the gods are present, and they are collectively deliberating the best course of action, presumably in their official rekstólar. Moreover, even if Fenrir had not enjoyed the right to safety through grið, the manner in which the Æsir bind him would certainly be illegal. Given Snorri's repeated descriptions of the Æsir discussing matters as a council of twelve (see Cole forthcoming), Fenrir would indeed have been judged eftir tólf manna dómi. This phrase normally refers to the convening of a jury, twelve apparently being the standard number for a jury both in Scandinavia and England from the thirteenth and fourteenth centuries onwards (Groot 1988, 5-7; Murley and Sutton 2014, 24-25). It seems paradoxical to us that the exercise of force should be illegitimate when performed with the assent of a jury. However, in the context of King Magnús Hákonarson's attempt to centralize the state - and theretowards to obtain a state monopoly on violence - the penalization of ad hoc juries makes perfect sense.

While the Æsir would have been damned by King Magnús's legislation, the obvious problem is that it was not formulated until after Snorri's death. It is not unthinkable that certain ideas in King Magnús's legislation had first been sketched out by his father, King Hákon. The general trend of state-centralization enacted by Magnús was a continuation of the project first undertaken by Hákon. Snorri was present at Hákon's court, where he could have been party to the embryonic discussions which one day came to fruition in Magnús's reforms. But here we are in the realm of pure conjecture. Indeed, Snorri's apparent sympathy for at least some aspects of rule by assembly (as seen in his depiction of Æsirist government as more Icelandic ping than Norwegian king, see Cole forthcoming) might suggest that even if he knew of the proposals found in GKS 1154, he would not necessarily have agreed with them.

Returning from intertextual conversations to the intratextual world of Snorra $E d d a$, it might be argued that the gods' ignoble behaviour in this case is excusable because they have not formally offered grið (truce, sanctuary) to Fenrir. However, such a defence, while potentially legally admissible, still says nothing good of the Æsir's character: even though they have not recited an official oath formula, they have nonetheless offered conditions of safety, vociferously maintained they were true, then demonstrated that they were not. Why do they accept the dishonour of lying, but refuse the dishonour of spilling blood in a holy place? There is something disingenuous about their supposed willingness to break an informal grið, yet not to defile a griðastaðr. Óðinn implies that the encounter with Fenrir is happening in Ásgarðr: 'Úlfinn fǫddu Æsir heima' (Snorri Sturluson in Faulkes 
1988, 27) (The Æsir raised the wolf at home).$^{28}$ As previously quoted, the explanation is then given that killing Fenrir there would constitute a blasphemy against the gods' vé (sacred grove) (the logic apparently being that a vé is a gridastadr). But who is to be worshipped in this vé? In Snorri's narrative frame, the entire pagan religion is a sort of confidence trick. The Æsir are charlatans magicians, yes, but well aware that they are not really divine — so why should it offend their religious sensibilities to see shrines to themselves desecrated? Even if one disregards the narrative frame and accepts that the Æsir actually are supposed to be gods, whom, then, are they planning to worship in their vé? ${ }^{29}$ Do the gods themselves have other gods? Or if the Æsir are their own objects of veneration, do they not have the authority to forgive the blasphemy they might commit against themselves, particularly as the stakes are so high? On serious reflection, Óðinn's explanation for the mistake of not killing Fenrir quickly begins to feel absurd.

Perhaps the real reason that the Æsir fail to kill Fenrir is that Æsirism is not an ideology that is capable of perceiving threats to itself. Is Óðinn embarrassed to admit to Gangleri that the real hamartia of the gods is not piety, but myopia? Just as Fenrir ultimately destroys Óðinn, Pórr kills the serpent Jǫrmungandr but is himself killed in the process from resulting splashes of the beast's venom: 'Pórr [] stígr paðan braut níu fet. Pá fellr hann dauðr til jarðar fyrir eitri pví er ormrinn blæss á hann' (Snorri Sturluson in Faulkes 1988, 50)30 (Pórr [ ] takes nine steps away. Then he falls down dead to the earth because of the poison which the serpent spewed on him). The same tool/weapon that gave the Æsir supremacy over the giants also becomes their undoing; the story would have run differently if Pórr had picked up a bow, like the god Ullr. But he doesn't. Mjǫllnir has always worked against the giants before, and so he steps into spitting range of the serpent with the blind confidence of a man who has only a hammer, and sees only nails (Lindow 1997, 170-71). Like Óðinn, Pórr too had a chance to eliminate his killer before Ragnarøkr during an attempt to catch Jormungandr on a fishing line. However, Pórr took a giant with him on that expedition, one named Hymir, who quailed at the sight of the serpent and let it go. Óðinn tells the story as a vindication of the giants' supposed cowardice and idiocy. Though I

${ }^{28}$ Codex Regius, fol. $7^{\mathrm{v}}$; Codex Trajectinus, fol. $8^{\mathrm{r}}$.

29 This conundrum is not unique to Snorri's telling of the myths. Voluspá (stanza 7) reads: 'Hittusk æsir | á Iðavelli, | peir er họrg ok hof | hátimbruðu' (Eddukvæði in Jónas Kristjánsson and Vésteinn Ólason 2014, 293) (The Æsir met | on Iðavolllr | they who built | tall altars and temples). This seems not to refer to the actual temples of the Viking Age, as the other actions described in stanzas 6-8 are intended to be occurring in Ásgarðr.

${ }^{30}$ Codex Regius, fol. 16 ; Codex Trajectinus, fol. 17v. 
wonder if Hymir is more guileful than he seems. It would make sense if Hymir deliberately let the serpent go, in an act of resistance tantamount to a moment of civil disobedience. After all, when you have spent a lifetime smashing the skulls of giants, and you then take a giant with you to help you pre-emptively kill the beast that will otherwise be your death, you cannot be all too surprised when that giant exhibits a lack of motivation in the workplace.

The Æsir are powerful and cunning, but they are not able to think ahead to the point where they will take decisions that hurt in the short term, in order to allow them to survive in the long term. Just like modern capitalists, the Æsir have established an order that suffers from bureaucratic inertia (on the love of the Æsir for arranging meetings, see Abram 2019, 135-40). ${ }^{31}$ This order is too shortsighted and too in love with its traditional ways of doing things to prevent its own destruction. When it falls, it will take the rest of the world with it. Regarding the poem Voluspá, Abram makes the following point about this self-destructive impulse, which could equally well apply to Snorri's Edda:

Odin can't help us, since he can't help himself. Thor's strength is just about a match for the world-serpent, but it is no use against fate. Perhaps if the gods had behaved better earlier on, perhaps if they had protected Baldr against Loki's machinations, or kept their promises in the wake of the war with the Vanir, the world might have been saved. Perhaps if people had kept faith with one another, respected the bonds that hold society together, adhered to a stricter moral code, they could have helped to forestall Ragnarök - for a while, at least. But according to the internal logic of fate in Völuspá, everything has happened as it must because everything will happen as it must. It leaves the pagan gods powerless to control a universe of their own making. Its fatalism suggests that the whole system is doomed to failure; we might go further and suggest that it is not worth saving. The völva's description of Ragnarök gives us little cause for hope. (Abram 2010, 163)

That Æsirism cannot prevent its own undoing is a corollary from the way it dreams of its future - or refuses to do so. As seen, socialism and fascism, and some strains of millenarianism are given to dreaming of exuberant, futuristic fantasies. But Æsirism is more like capitalism, in that it generally either is incapable of imagining the future, or that it makes no promises that it will deliver a particularly pleasant version thereof. (There are some fringe exceptions amongst anarcho-capitalist thinkers, though in these cases one suspects that the utopian element has come

31 The 'love affair' of capitalism with bureaucracy is treated by Graeber 2015. See also Pecchenino 1993, 25-37. In fact, it ought to be protested that the political culture of the Æsir is not overly bureaucratic - indeed, in many ways it is anti-bureaucratic because it exhibits virtually no trace of alienation in a Marxian sense. However, these are arguments for another time. 
from their anarchist heritage rather than their capitalist beliefs. ${ }^{32}$ One thinks of capitalism's ecological destructiveness primarily in terms of capitalism's rapacious capabilities, the soaring edifices it builds, the forests it consumes with its hunger. One does not think of its ineffectualness; the damage capitalism causes not out of its strength, but out of its inabilities. True, capitalism can build skyscrapers, give an iPhone to most of the population of the Eurasian continent, etc. Capitalism can do these great things, but it is ideologically incapable of something as simple as to think more than two steps ahead. Tell your shareholders that their profits will dip today, so that they can be sustainable tomorrow, and they will be jumping ship before teatime (a simple iteration of game theory; even if the shareholder knows they ought to stay the course, the safest option is to leave first so as to rule out the risk of being the last). So it is with Æsirism. Opportunities to do things differently repeatedly offer themselves. But, as Abram stresses in the quote above, the Æsir turn them down, either because they are convinced that nothing can change the seeress's prophecy in Voluspá, or because they are too myopic to realize their danger. The effect of this refusal to change is that Æsirism works, insofar as it assures dominance over the giants and thereby prosperity for the Æsir. Until one day, it doesn't.

The comparison between Æsirism and capitalism has the potential to be more illuminating than a rhetorical sideswipe at the current mode of production. One of the recurrent questions posed by critics of capitalism is from where its contentment with its own imperfections springs (Mulgan 2013, 79-103). Do capitalists self-destructively continue to cause environmental destruction and relentless misery because they are unaware of the consequences of their action? (I.e. are they blind?) Or do they believe that there is simply no better way? (I.e. are they fatalist?) The present study is not the venue to resolve that question concerning capitalism, but we can attempt to answer the same question posed of Æsirism. Abram is right to prefer the fatalist interpretation in the context of Voluspá, and indeed elsewhere in his monograph where he offers an impressive, holistic view of Old Norse myth across the sources. In the fictional world of

32 The frequent scepticism of capitalists towards utopia is summed up in the pithy statements of Ludwig von Mises: 'The socialist paradise will be the kingdom of perfection, populated by completely happy supermen. All socialist literature is full of such nonsense. But it is just this nonsense that wins it the most supporters [...] the earth is no paradise' $(1962,17,63)$. For an example of the occasional utopianism of anarcho-capitalism (albeit a 'utopia' that sometimes seems more like a dystopia to a non-anarcho-capitalist), see Hoppe 2001. That anarchocapitalist utopianism often draws on the case study of the Icelandic Commonwealth is a matter beyond the scope of the present study. 
Snorri's $E d d a$, understood on its own terms and as a self-contained work, a slightly different conclusion recommends itself.

In the Poetic Edda Óðinn is often to be found embarking on various knowledge quests, often with the explicit aim of discovering more about the apocalypse (e.g. the poems Voluspá, Vafprúdnismál, Grimnismál). But in Snorri’s Edda, although all the aforementioned poems are cited, this aspect of Óðinn's personality is very much downplayed. Frigg, his wife, is said to know 'ørlog manna pótt hon segi eigi spár' (Snorri Sturluson in Faulkes 1988, 21) 33 (the fates of men, though she does not tell prophecies). The gods as a whole discover a prophecy about Fenrir, though Óðinn's specific contribution to this discovery is not mentioned (Snorri Sturluson in Faulkes 1988, 27). ${ }^{34}$ In the euhemerist narrative frame, Óðinn and the other Æsir are said to have the gift of prophecy for themselves, though this is not quite the same thing as having a passion for gnostic adventures (Snorri Sturluson in Faulkes 1988, 5, 7). ${ }^{35}$ As one might expect from a work of high medieval Christian learning, Snorra Edda portrays Óðinn much more as a purveyor of falsehoods than a seeker after wisdom.

Snorri's version of Óðinn is not fatalistic; he is not obsessively seeking out prophecies as the Poetic Edda's Óðinn is. Therefore, he cannot be resigned to a fate decreed by destiny. Compared to other sources for Old Norse mythology, Snorri appears to stress the theme of blindness. That Óðinn is a one-eyed god is found in Voluspá when the seeress warns: "Allt veit ek, Óðinn, | hvar pú auga falt: | í inum mæra| Mímisbrunni"' (Eddukveði in Jónas Kristjánsson and Vésteinn Ólason 2014, 298) ('I know everything, Óðinn, | where you hid your eye | in Mímir's | famed well'). This particular description of sightlessness therefore cannot be attributed to Snorri. But the blindness of Họdr, the god who kills Baldr, is uniquely Snorronic, in that no other source implies Họ rr could not see. According to Saxo Grammaticus and the later Danske Rimkrønike, Hǫðr/ Høtherus/Høtther is a mighty warrior, apparently with 20-20 vision. As Óðinn tells Gangleri, when Hǫðr is first introduced: 'Họðr heitir hann Ássinn. Hann er blindr. OErit er hann styrkr. En vilja mundu goðin at penna Ás pyrfti eigi at nefna, pvíat hans handaverk munu lengi vera hǫfð at minnum með goðum ok mǫnnum' (Snorri Sturluson in Faulkes 1988, 26) ${ }^{36}$ (There is a member of the Æsir called Hǫðr. He is blind. He is incredibly strong. And the gods would rather

${ }^{33}$ Codex Regius, fol. 6r; Codex Trajectinus, fol. $6^{\mathrm{v}}$.

${ }^{34}$ Codex Regius, fol. $7^{\mathrm{v}}$; Codex Trajectinus, fol. $8^{\mathrm{r}}$.

${ }^{35}$ Codex Regius, fol. $1^{\mathrm{r}-\mathrm{v}}$; Codex Trajectinus, fols $1^{\mathrm{v}}, 2^{\mathrm{r}}$.

${ }^{36}$ Codex Regius, fol. $7^{\mathrm{r}}$; Codex Trajectinus, fol. $7^{\mathrm{v}}$. 
this member of the Æsir not be mentioned, because his deeds will long be held in the memories of gods and men).

The significance of Hǫðr's blindness tolerates various interpretations. Sophus Bugge was transparent in his attempt to read the story genealogically: 'Den blinde Họðr er den blinde Longinus, som gjennemborer Kristus' (Bugge 1881-89, 35) (The blind Hǫr is the blind Longinus, who pierces Christ). More nuanced allegorical readings in this vein are offered by Heather O'Donohue (2005) and Arthur Mosher (1983, 305-15; see also Cole 2017, 248). In the opposite direction, Jan de Vries posited that Họðr's blindness signified his Odinic identity (Óðinn lacking the use of one eye, Hǫr lacking the use of two) and that therefore Óðinn killed his own son (1955, esp. 57-58). ${ }^{37}$ Perhaps most colourfully, Anatoly Liberman suggests that 'his blindness is that of the mole, of an enemy of light' $(2004,22)$, meaning that 'he is isolated and helpless in Snorri's tale, but we can be sure that in the crude atmosphere of the primitive myth he did not need his eyes to find his way around' (24). Essentially, the argument here seems to be that Hǫ $\partial \mathrm{r}$ is blind, but he nonetheless can see. This is a radical proposition, though to my mind it seems like an overly taxing contradiction in terms. A similar, but less mystical, sort of argumentation is offered by Lois Bragg, who emphasizes Hǫðr's strength and apparent martial capabilities:

That Höd cannot possibly have been regarded by Snorri or by the heathen Norsemen who developed the myth as an 'invalid' or 'simpleton' is clear from many details, not least of which is the fact that Ódin fathers a new son specifically to kill Höd, which would hardly be necessary, let alone honorable, if Höd were in fact an invalid. (Bragg 2004, 16)

Annette Lassen provides an elegant reading rooted in nif, which resolves the contrast between blindness and strength with an almost psychoanalytic approach:

Høds blindhed kan på denne måde ses som symbolet på, at han er nidding. Ved at dræbe sin bror begår han niddingsværk. Hans blindhed er tegnet på hans svaghed, hans umandighed, der, som vi ved fra Snorri, ikke er af fysisk karakter, for Hød er nemlig meget stærk. Samtidig er det tegn på den manglende indsigt, der er forudsætningen for hans forbrydelse. Hvis man tolker Loke som en personifikation af Høds misundelse, er det imidlertid ikke fyldestgørende at tolke Høds blindhed som symbolet på hans manglende indsigt i handlingen. Loke handler af ond vilje, og at Hød ureflekteret lader sig bruge af denne ond vilje, viser Høds afstumpethed. (Lassen 2003, 79)

37 A much more convincing progression, unlike de Vries wholly untainted by fascist ideology, is offered by Mills 2017; see also Harris 2007. 
(The blindness of Họðr can, in this way, be seen as a symbol that he is a shameful person. By killing his brother he commits an act worthy of shame. His blindness is a sign of his weakness, his unmanliness, which, as we know from Snorri, is not physical in character, because Hǫr is actually very strong. At the same time, it is a sign of his lacking insight, which is the precondition for his crime. If one interprets Loki as a personification of Họðr's envy, it is however not sufficient to interpret Hǫðr's blindness as a symbol of his lacking insight into his deed. Loki acts out of evil intentions, and that Hǫðr unreflectively lets himself be used by these evil intentions demonstrates Hǫðr's insensitivity.)

These are all ingenious ways to account for the supposed tension between Hǫðr's strength and his blindness. Even the post-Buggean readings do this, insofar as they imply that the blindness must be a later, Christian accretion to the body of Old Norse myth. However, if one allows for the possibility that Snorri is tacitly passing comment on the ideological principles of the gods, the tension disappears. Indeed, it becomes quite appropriate for Óðinn/Snorri to introduce Hǫðr with the words: 'Hann er blindr. CErit er hann styrkr' (He is blind. He is incredibly strong). After all, that is the entire problem of the Æsir. They have the strength to expropriate the giants, so they do. They don't see that doing so will create a race of implacable enemies. They have the strength to capture Fenrir, but as previously argued, they do not see the need to kill him. Pórr indentures a giant to help him kill the Miðgarðsormr, and then appears surprised when the giant is not as helpful as perhaps he could be. 'Strong but blind' is a serviceable character sketch of Æsirism, and Hǫr is a perfect metaphor for that hamartia. The debate over how culpable Hǫðr is for his actions can be thought of as moot; Hǫðr is ideology in the flesh in Žižek's terms, 'he does not know he is doing it, but he is doing it anyway'.

\section{Conclusion: Snorri's Relationship with Asirism}

Whether Snorri himself thought that Æsirism was a benevolent or malevolent ideology must depend on to what extent he intended the Æsir to be the heroes or the villains of the Edda. The question is far from being black and white. Through Gylfi, Snorri adopts a sensitive, questioning tone with his subjects. The good is drawn out as well as the bad. Gylfi's inquisitive persona has occasionally drawn criticism, e.g. the characterization of the visiting king as 'something of a guileless fool' (Lindow 1997, 62, a much more generous assessment is provided by McTurk 1994, esp. 7-10). However, though Gylfi in the end succumbs to Óðinn's plot, this failure can be understood as an unintended consequence of his attempt to anatomize Æsirism meticulously: a quixotic attempt to articulate an ideology in purely neutral terms. Snorri/Gylfi might very well have been subscribing to the 
delicate empathetic method of interrogation favoured by Abelard: 'Nulla quippe, ut quidam nostrorum meminit, adeo falsa est doctrina ut non aliqua intermisceat uera; et nummam adeo friuolam esse disputationem arbitror, ut non aliquod habeat documentum' (Abelard 2001, 7) (For, as one of our writers once noted, no teaching is so false, that there is not truth mixed in with it; and, in my view, no debate is so frivolous that it does not teach us something).

Snorri does appear to treat the Æsir — and their political philosophy — with a degree of affection. As we have seen, the way the Æsir govern themselves appears very much like an idealized version of the political system in which Snorri himself was raised. Despite the fact that Snorri actually favoured Icelandic union with the Norwegian Crown, this is one aspect of Æsirism that is apparently intended to function well: none of the Æsir's woes can be traced back to the fact that Óðinn does not adopt the title of king. Snorri's versions of the gods also exhibit many of the virtues which contemporary saga-writing considered praiseworthy. Snorri could be using a stock-description of a saga hero when he introduces Óðinn with the words 'hann var ágætr maðr af speki ok allri atgervi' (Snorri Sturluson in Faulkes $1988,5)^{38}$ (he was a man excellent in knowledge and in all accomplishments). Of Pórr we hear that 'svá var hann fagr álitum er hann kom með ǫðrum mǫnnum

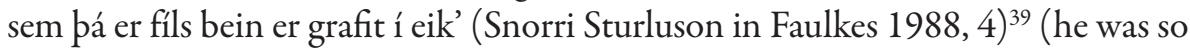
beautiful in appearance when he appeared amongst other people that it was like ivory inlaid in oak). The extremely flattering description of Baldr is well known, and from Óðinn's mouth rather than Snorri's narrative voice, but it is nonetheless indicative that the Æsir are far from being pantomime villains.

Drawing on Voluspá stanzas 59-65, Snorri even permits a few of the gods to enjoy a sort of afterlife, if Óðinn's words can be believed. Lindow $(1997,178)$ calls this scene 'Snorri's coda', which emphasizes that, although not Snorri's original creation, it does feel like an appendix; a cherishing embrace at a bittersweet farewell, rather than an integral part of the story. Highlighting the ideological charge of Snorri's Edda, Ursula Dronke describes this curious rebirth as a 'dialectic of death' and a 'vehicle of vitality' (1989, 41-42). Óðinn and Pórr die at Ragnarøkr, but their sons magically return from the dead, and settle where Ásgarðr once stood. Baldr and Hǫðr are resurrected too, without a hint of ill will between them:

${ }^{38}$ Codex Regius, fol. $1^{\mathrm{r}}$; Codex Trajectinus, fol. $1^{\mathrm{v}}$.

${ }^{39}$ Codex Trajectinus, fol. $1^{\text {r }}$; it will be remembered that Codex Regius now lacks the first folio of the prologue. 
'Upp skýtr jǫrðunni pá ór sænum ok er pá grœn ok fogr. Vaxa pá akrar ósánir. Viðarr ok Váli lifa svá at eigi hefir særinn ok Surtalogi grandat peim, ok byggja peir á Iðavelli, par sem fyrr var Ásgarðr. Ok par koma pá synir Pórs, Móði ok Magni, ok hafa par Mjǫllni. Pví næst koma par Baldr ok Hǫðr frá Heljar. Setjask pá allir samt ok talask við ok minnask á rúnar sínar ok rœða of tíðindi pau er fyrrum họfou verit, of Miðgarðsorm ok um Fenrisúlf. Pá finna peir í grasinu gulltǫflur pær er Æsirnir hǫfou átt.' (Snorri Sturluson in Faulkes 1988, 53-54) ${ }^{40}$

(The earth then shoots up from the sea, and it is green and beautiful. Fields then grow without needing to be sown. Viðarr and Váli live as though they had never been wounded, and as though the flame of Surt had never harmed them, and they dwell on Iðavellir, where Ásgarðr used to be. Then the sons of Pórr come, Móði and Magni, and they have Mjǫllnir with them. Next come Baldr and Hǫðr from Hel. They all sit down together and talk, and remind each other of their runes [alt. 'secrets'] and speak of the things which used to be, of the serpent of Miðgarðr and of the wolf of Fenrir. They find in the grass those golden chess pieces which the Æsir used to own.) $)^{41}$

Snorri appears to have had complicated feelings about the Æsir. He clearly identified with them in some sense. According to Islendinga saga, he named his booth at the Alpingi 'Valhọll' (Valhalla) (Sturla Pórðarson in Kålund 1906, 424, cf. 425, 461). But Snorri also had the equivocacy of a scholar: at one point in Hákonar saga Hákonarsonar, he composes an allegorical verse, insulting Gautr Jónsson (d. 1270) by comparing him to Óðinn (Sturla Pórðarson in Sverrir Jakobsson, Porleifur Hauksson, and Tor Ulset 2013, 42). By implication, then, his feelings towards Óðinn cannot have been solidly positive. Indeed, despite some apparent sympathy on Snorri's part, it is the negative aspects of the Æsir and their ideology which leave a lasting impression. The gods do not act to save themselves when they have the chance. They act in treacherous ways, both towards their enemies (e.g. the Fenrisulffr, the giant builder) and each other (Loki). Their aggressive expropriation of the giants leaves them surrounded by alienated peoples, who jump at the chance to bring down their erstwhile oppressors. The predominant mood of Snorra Edda alternates between melancholy and frustration - and it is the flawed principles of the Æsir which are responsible. In Snorri's narrative frame, Óðinn is not a brooding gnostic. Instead, he is a charlatan and conjurer. He is intent upon bamboozling the Old Norse-speaking

${ }^{40}$ Codex Regius, fol. 17 ; Codex Trajectinus, fol. $18^{\mathrm{r}-\mathrm{v}}$.

${ }^{41}$ One wonders if the chess pieces are intended to be a metaphor for the Old Norse poetic tradition as a whole. They are offered to Gylfi by Óðinn, a god of poetry. Moreover, they are the sole radiant good to have survived from the darkness of paganism into the joy of the Christian era. Naturally, this suggestion can only ever remain speculative. 
peoples into accepting a false religion, plunging their souls into peril. And to what end? Nothing but personal enrichment. He is not even a particularly competent ruler. Despite some successful ruses against the giants, the Æsir are undone by blindness rather than the superiority of their foes. Stories are told of a Golden Age that would be restored, were it not for some evil giantesses. Gylfi accepts this narrative, his mind addled by a colourful torrent of actual wisdom, half-truths, and vapid fantasies. But as Óðinn disappears into Fenrir's jaws, and Pórr staggers to his death drenched in venom, Snorri has made one thing abundantly clear: Æsirism will not make Ásgarðr great again.

\section{Acknowledgements}

I am grateful to Joseph Harris, Nicolas Meylan, Kristen Mills, and Lukas Rösli for their many helpful comments on an early draft of this paper. My thanks also go to Jarvis McInnis for introducing me to the work of Ida B. Wells. Any shortcomings are my own.

\section{A Note on the Text}

In the time between this article being submitted for review and its appearance in print, Christopher Abram has published Evergreen Ash: Ecology and Catastrophe in Old Norse Myth and Literature. At the stage of receiving final proofs I was still making my way through this exciting book, though it is immediately apparent to me that our methods have much in common, insofar as I offer comparisons between the political '-isms' of the modern period and Snorri's mythmaking (see for example Abram 2019, 38-40). I have not yet found instances where we reach exactly the same conclusions about the same specific moments in Old Norse myth, but if future readers discover such cases I can only apologize and ask that Abram's claims be treated as primary. It ought to be acknowledged that my whole approach to mythology has been strongly conditioned by the happy, formative years I spent as Abram's student. 


\section{Works Cited}

\section{Manuscripts}

Codex Regius $=$ Copenhagen, Det Kongelige Bibliotek, GKS 2367 4to

Codex Trajectinus = Utrecht, University Library Utrecht, Traj 1374

\section{Primary Sources}

Bjarni Aðalbjarnarson, ed. 1941. Snorri Sturluson. Heimskringla, I, Íslenzk fornrit 26, Reykjavík: Hið íslenzka fornritafélag

Bugge, Alexander, ed. 1913. Diplomatarium Norvegicum, Xvir.2, Christiania: Mallingske Bogtrykkeri

Faulkes, Anthony, ed. 1988. Snorri Sturluson. Edda: Prologue and Gylfaginning, London: Viking Society for Northern Research

Faulkes, Anthony, ed. 1998. Snorri Sturluson. Edda: Skáldskaparmál, I, London: Viking Society for Northern Research

Flom, George T., ed. 1937. The Old Norwegian General Law of the Gulathing according to Codex Gl.k.S. 1154 Folio, Urbana: University of Illinois

Goold, George P., ed. 1999. Homer. Homer: Iliad: Books 13-24, Loeb Classical Library 171, Cambridge, MA: Harvard University Press

Goold, George P., ed., Henry Rushton Fairclough, trans. 1999. Virgil. Virgil, I: Eclogues. Georgics. Aeneid I-VI, Loeb Classical Library 63, Cambridge, MA: Harvard University Press

Indrebø, Gustav, ed. 1966 [1931]. Gamal norsk homiliebok: Cod. AM 619 4to, Oslo: Universtitetsforlaget

Jónas Kristjánsson and Vésteinn Ólason, ed. 2014. Eddukveði, I, Reykjavik: Hið íslenzka fornritafélag

Kalinke, Marianne E., ed. 1999. Norse Romance, I: The Tristan Legend, Cambridge: Brewer

Kålund, Kristian, ed. 1906. Sturla Pórðarson. Sturlunga saga, I, Copenhagen: Gylendalske Boghandel

Marenbon, John, and Giovanni Orlandi, eds. 2001. Peter Abelard. Collationes, Oxford: Clarendon

Miller, Frank Justus, ed. and trans., George P. Goold, rev. 1916. Ovid. Ovid: Metamorphoses, I: Books 1-8, Loeb Classical Library 42, Cambridge, MA: Harvard University Press

Most, Glenn W., ed. and trans., 2006. Hesiod. Hesiod: Theogony. Works and Days. Testimonia, Loeb Classical Library 57, Cambridge, MA: Harvard University Press

$O E D=$ Oxford English Dictionary, 3rd edn, Oxford: Oxford University Press, 2010

Sigurðr Nordal, ed. 1933. Egils saga Skalla-Grimssonar, Íslenzk fornrit 2, Reykjavík: Hið íslenzka fornritafélag 
Sverrir Jakobsson, Porleifur Hauksson, and Tor Ulset, eds. 2013. Sturla Pórðarson. Hákonar saga Hákonarsonar, II: Magnúss saga Lagabotis, Íslenzk fornrit 32, Reykjavík: Íslenzka fornritafélag

Vilhjálmur Finsen, ed. 1974. Grágás: Konungsbók. Genoptrykt efter Vilhjálmur Finsens udgave 1852, I, Odense: Odense Universitetsforlag

\section{Secondary Sources}

Abram, Christopher. 2011. Myths of the Pagan North: The Gods of the Norsemen, London: Continuum

Abram, Christopher. 2019. Evergreen Ash: Ecology and Catastrophe in Old Norse Myth and Literature, Charlottesville: University of Virginia Press

Arendt, Hannah. 1978. 'From an Interview', New York Review of Books, 26 October 1978, 18

Ármann Jakobsson. 1999. 'Le Roi Chevalier: The Royal Ideology and Genre of Hrólfs saga kraka', Scandinavian Studies 71, 139-66

Ármann Jakobsson. 2015. 'King Sverrir of Norway and the Foundations of his Power: Kingship Ideology and Narrative in Sverris saga', Medium evum 84, 109-35

Bagge, Sverre. 1991. 'Propaganda, Ideology and Political Power in Old Norse and European Historiography: A Comparative View', in L'Historiographie médiévale en Europe: Actes du colloque organisé par la Fondation européenne de la science au Centre de recherches historiques et juridiques de l'Université Paris I du 29 mars au ler avril 1989, ed. Jean-Phillippe Genet, Paris: Presses du CNRS, 1099-1208

Bagge, Sverre. 1991. Society and Politics in Snorri Sturluson's 'Heimskringla', Berkeley: University of California Press

Bagge, Sverre. 1993. 'Ideology and Propaganda in Sverris saga', Arkiv for nordisk flologi $108,1-18$

Ballif Straubhaar, Sandra. 2001. 'Nasty, Brutish, and Large: Cultural Difference and Otherness in the Figuration of the Trollwomen of the Fornaldar sögur', Scandinavian Studies 73, 105-24

Barr, James. 1974. 'Philo of Byblos and his "Phoenician History"', Bulletin of the John Rylands Library 57, 17-68

Barthes, Roland (trans. Annette Lavers). 1972. Mythologies, New York: Hill \& Wang

Bhabha, Homi K. 1983. 'The Other Question', Screen 24.6, 18-36

Bjarni Aðalbjarnarson. 1941. Notes to Heimskringla, I, Íslenzk fornrit 26, Reykjavík: Hið íslenzka fornritafélag

Björn M. Ólsen. 1905. 'Er Snorri Sturluson höfundur Egils sögu?', Skirnir 79, 363-68

Bragg, Lois. 2004. Oedipus borealis: The Aberrant Body in Old Icelandic Myth and Saga, Madison: Fairleigh Dickinson University Press

Bugge, Sophus. 1881-89. Studier over de nordiske Gude- og Heltesagns Oprindelse, I, Christiania: Cammermeyer

Cleasby, Richard, and Guðbrandur Vigfússon. 1874. An Icelandic-English Dictionary, Oxford: Oxford University Press 
Clunies Ross, Margaret. 1994. Prolonged Echoes: Old Norse Myths in Medieval Northern Society, I, Odense: Odense University Press

Clunies Ross, Margaret. 2005. A History of Old Norse Poetry and Poetics, Cambridge: Brewer

Clunies Ross, Margaret. 2014. 'Royal Ideology in Early Scandinavia: A Theory versus the Texts', The Journal of English and Germanic Philology 113, 18-33

Cohn, Norman. 1970. The Pursuit of the Millennium: Revolutionary Millenarians and Mystical Anarchists of the Middle Ages, Oxford: Oxford University Press

Cole, Richard. 2015. 'Racial Thinking in Old Norse Literature: The Case of the Blámaðr', Saga-Book 39, 21-40

Cole, Richard. 2017. 'Snorri and the Jews', in Old Norse Mythology: Comparative Perspectives, ed. Pernille Hermann and others, Milman Parry Collection of Oral Literature 3, Cambridge, MA: Harvard University, 243-68

Cole, Richard. Forthcoming. 'Æsirism: The Impossibility of Ideological Neutrality in Snorra Edda', in Myths and Ideologies: Critical Studies in Political Uses of Old Norse Myths, ed. Nicolas Meylan and Lukas Rösli, Turnhout: Brepols

DeAngelo, Jeremy. 2010. 'The North and the Depiction of the Finnar in the Icelandic Sagas', Scandinavian Studies 82, 257-86

Deleuze, Gilles, and Félix Guattari (trans. Brian Massumi). 2011. A Thousand Plateaus: Capitalism and Schizophrenia, London: Continuum

Dronke, Ursula. 1989. 'Marx, Engels, and Norse Mythology', Leeds Studies in English 20, 29-45

Fassin, Éric, and Mathieu Trachman. 2013. 'Voiler les beurettes pour les dévoiler: les doubles jeux d'un fantasme pornographique blanc', Modern \& Contemporary France 21, 199-217

Faulkes, Anthony. 1988. 'Introduction', in Edda: Prologue and 'Gylfaginning', London: Viking Society for Northern Research, xi-xxxiii

Foote, Peter. 1984. 'Observations on "Syncretism” in Early Icelandic Christianity', in Aurvandilstá: Norse Studies, ed. Michael Barnes, Hans Bekker-Nielsen, and Gerd Wolfgang Weber, Odense: Odense University Press, 84-100

Friedman, David. 1979. 'Private Creation and Enforcement of Law: A Historical Case', Journal of Legal Studies 8, 399-416

Graeber, David. 2015. The Utopia of Rules: On Technology, Stupidity, and the Secret Joys of Bureaucracy, New York: Melville House

Griffin, Roger. 1991. The Nature of Fascism, London: Routledge

Groot, Roger D. 1988. 'The Early-Thirteenth-Century Criminal Jury', in Twelve Good Men and True: The Criminal Trial Jury in England, 1200-1800, ed. James S. Cockburn and Thomas A. Green, Princeton: Princeton University Press, 3-35

Hallberg, Peter. 1962. Snorri Sturluson och Egils saga Skallagrimssonar: Ett forsök till språkligförfattarbestämning, Reykjavík: Bókaútgáfa Menningarsjóðs

Handy, Lowell K. 1994. Among the Host of Heaven: The Syro-Palestinian Pantheon as Bureaucracy, Winona Lake: Eisenbrauns

Harris, Joseph. 2007. 'Homo necans borealis: Fatherhood and Sacrifice in Sonatorrek', in Myth in Early Northwest Europe, ed. Stephen O. Glosecki, Medieval and Renaissance Texts and Studies 320, Turnhout: Brepols, 153-73 
Hook, Derek. 2005. 'The Racial Stereotype, Colonial Discourse, Fetishism, and Racism', Psychoanalytic Review 92, 701-34

Hoppe, Hans-Hermann. 2001. Democracy: The God That Failed: The Economics and Politics of Monarchy, Democracy, and Natural Order, Rutgers: Transaction

Jóhanna Katrín Friðríksdóttir. 2013. “Gerðit Hon ... Sem Konor Aðrar”. Women and Subversion in Eddic Heroic Poetry', in Revisiting the Poetic Edda: Essays on Old Norse Heroic Legend, ed. Paul Acker and Carolyne Larrington, New York: Routledge, 117-35

Koht, Halvdan. 1910. 'Om Haalogaland og Haaløygætten', Historisk tidsskrift 4, 1-16

Larrington, Carolyne. 1992 [1993]. “'What Does Woman Want?” Mær und munr in Skirnismál, Alvissmál 1, 3-16

Lassen, Annette. 2003. Øjet og blindheden i norrøn litteratur og mytologi, Copenhagen: Museum Tusculanum

Lee, Josephine. 2001. 'Bodies, Revolutions, and Magic: Cultural Nationalism and Racial Fetishism', Modern Drama 44, 72-90

Liberman, Anatoly. 2004. 'Some Controversial Aspects of the Myth of Baldr', Alvissmál $11,17-54$

Lindow, John. 1997. Murder and Vengeance among the Gods: Baldr in Scandinavian Mythology, Folklore Fellows Communications 262, Helsinki: Suomalainen Tiedeakatemia

Lindow, John. 2001. Norse Mythology: A Guide to the Gods, Heroes, Rituals, and Beliefs, Oxford: Oxford University Press

Lönnroth, Lars. 1977. 'Skirnismál och den fornisländska äktenskapsnormen', in Opuscula Septentrionalia: Festskrift til Ole Widding, ed. Bent C. Jacobsen and others, Bibliotheca Arnamagnaeana 35.2, Copenhagen: Reitzel

McKinnell, John. 2014. 'On Heiðr and Gullveig', in Essays on Eddic Poetry, ed. Donata Kick and John D. Shafer, Toronto: University of Toronto Press, 34-58

McTurk, Rory. 1994. 'Fooling Gylfi: Who Tricks Who?', Alvissmál 3, 3-18

Meylan, Nicolas. 2018. 'Mad Love: Myth, Kingship, and the Dissolution of the State', Viking and Medieval Scandinavia 14, 135-52

Mills, Kristen. 2017. 'Does Heilagt Tafn in Húsdrápa 10 Mean "Holy Sacrifice"? Reassessing the Evidence', Viking and Medieval Scandinavia 13, 145-64

Mises, Ludwig von (trans. Ralph Raico). 1962. The Free and Prosperous Commonwealth: An Exposition of the Ideas of Classical Liberalism, Princeton: Van Nostrad

Mitchell, Stephen A. 2011. Witchcraft and Magic in the Nordic Middle Ages, Philadelphia: University of Pennsylvania Press

Mosher, Arthur D. 1983. 'The Story of Baldr's Death: The Inadequacy of Myth in the Light of Christian Faith', Scandinavian Studies 55, 305-15

Mulgan, Geoff. 2013. The Locust and the Bee: Predators and Creators in Capitalism's Future, Princeton: Princeton University Press

Mundal, Else. 1996. 'The Perception of the Saamis and their Religion in Old Norse Sources', in Shamanism and Northern Ecology, ed. Juha Pentikäinen, Berlin: de Gruyter, 97-116

Murley, John A., and Sean D. Sutton. 2014. The Supreme Court against the Criminal Jury: Social Science and the Palladium of Liberty, Lanham: Lexington

O’Donoghue, Heather. 2005. 'What Has Baldr to Do with Lamech? The Lethal Shot of a Blind Man in Old Norse Myth and Jewish Exegetical Traditions', Medium avum 72, 82-107 
Pecchenino, Rowena A. 1993. 'The Behavior of Corporate Bureaucrats', in Bureaucracy: Three Paradigms, ed. Neil Garston, Boston: Kluwer, 25-37

Phelpstead, Carl. 2003. 'The Sexual Ideology of Hrólfs saga kraka', Scandinavian Studies $75,1-24$

Phelpstead, Carl. 2014. 'Myth-Making and Sub-Creation', in A Companion to J. R. $R$. Tolkien, ed. Stuart D. Lee, Oxford: Wiley Blackwell, 79-91

See, Klaus von (trans. Bill McCann). 2001. 'Snorri Sturluson and the Creation of a Norse Cultural Ideology', Saga-Book 25, 367-93

Steinsland, Gro. 2011a. 'Ideology and Power in the Viking and Middle Ages. Scandinavia, Iceland, Ireland, Orkney and the Faeroes', in The Northern World: Ideology and Power in the Viking and Middle Ages: Scandinavia, Iceland, Ireland, Orkney and the Faeroes, ed. Gro Steinsland and others, The Northern World 52, Leiden: Brill, 1-15

Steinsland, Gro. 2011b. 'Origin Myths and Rulership: From the Viking Age Ruler to the Ruler of Medieval Historiography: Continuity, Transformations and Innovations', in The Northern World: Ideology and Power in the Viking and Middle Ages: Scandinavia, Iceland, Ireland, Orkney and the Faeroes, ed. Gro Steinsland and others, The Northern World 52, Leiden: Brill, 15-68

Sverrir Jakobsson. 2016. 'Saracen Sensibilities: Muslims and Otherness in Medieval Saga Literature', The Journal of English and Germanic Philology 115, 213-38

Tolley, Clive. 1997. 'The Mill in Norse and Finnish Mythology', Saga-Book 24, 63-82

Torfi H. Tulinius (trans. Victoria Cribb). 2014. The Enigma of Egill: The Saga, the Viking Poet, and Snorri Sturluson, Islandica 57, Ithaca: Cornell University Press

Turville-Petre, E. O. G. 1964. Myth and Religion of the North: The Religion of Ancient Scandinavia, London: Weidenfeld \& Nicolson

Vries, Jan de. 1955. 'Der Mythos von Balders Tod', Arkiv för nordisk filologi 70, 39-60

Wanner, Kevin J. 2008. Snorri Sturluson and the 'Edda': The Conversion of Cultural Capital in Medieval Scandinavia, Toronto: University of Toronto Press

Wells, Ida B. 1997 [1892-1900]. Southern Horrors and Other Writings: The Anti-Lynching Campaign of Ida B. Wells, ed. Jacqueline Jones Royster, Boston: Bedford

Zachrisson, Inger. 2008. 'The Sámi and their Interaction with the Nordic Peoples', in The Viking World, ed. Stefan Brink and Neil Price, London: Routledge, 32-39

Zheng, Robin. 2016. 'Why Yellow Fever Isn't Flattering: A Case against Racial Fetishes', Journal of the American Philosophical Association 2, 400-19

Žižek, Slavoj. 2003. The Puppet and the Dwarf: The Perverse Core of Christianity, Cambridge, MA: MIT University Press

Žižek, Slavoj. 2008. The Sublime Object of Ideology, London: Verso 
